IJSSHE-International Journal of Social Sciences, Humanities and Education Volume 3, Number 1, 2019

ISSN 2521-0041

\title{
DETERMINANTS OF MATHEMTICS-RELATED CAREer CHOICE AMONg SENIOR SECONDARY SCHOOL STUDENTS IN MAKURDI METROPOLIS, BENUE STATE, NigERIA
}

\author{
Joshua Abah Abah \\ University of Agriculture, Makurdi, Nigeria \\ Terungwa James Age \\ University of Agriculture, Makurdi, Nigeria \\ George Idoko Agada \\ University of Agriculture, Makurdi, Nigeria
}

\begin{abstract}
This study was designed to identify the determinants of mathematics-related career choice among senior secondary school students in Makurdi metropolis, Benue State, Nigeria. It explicitly focused on parents influence, academic ability, peer group influence, influence of various teaching methods employed in teaching mathematics, students' interest, gender differences and role models influences as basic determinants of mathematics-related career choice. A survey research design was employed for the study, with the researcher developed Students Career Determinant Questionnaire - SCDQ (Cronbach Alpha Coefficient = 0.82) administered to a sample of 125 senior secondary school students who want to major in mathematics-related careers. These students were drawn randomly from five different secondary schools chosen via stratified random sampling in Makurdi metropolis, Benue State, Nigeria. Mean and standard deviation were used to answer the research questions. Analysis of the data obtained from the $S C D Q$ revealed that parents have a huge influence on senior secondary school students' choice of career even if the careers of such parents may not be mathematics inclined and the parents may not insist or suggest that their students major in mathematics related careers. The study also revealed that career choice determinants such as students' academic ability (cluster mean score $=2.73$ ), peer group influences (cluster mean score $=2.69)$, various teaching methods employed in schools (cluster mean score $=$ 3.05), students interest (cluster mean score $=2.89$ ), gender differences (cluster mean score $=2.64$ ) and role model influences (cluster mean score $=2.68$ ), all have positive high influences on mathematics related career choice decisions of students. The results indicated that the various teaching methods employed in schools have the highest influence on mathematics-related career
\end{abstract}


choice among senior secondary school students with a cluster mean of 3.05. Based on these findings it was recommended that mathematics teachers should endeavour to employ modern teaching methods in their classroom lessons to ensure attainment of mathematics related-career goals among these secondary school students.

\section{KEYWORDS}

Career, Career choice, Career determinants, Mathematics Education

\section{INTRODUCTION}

The selection of a career is a decision every individual is faced with from child hood till the individual finally majors in a particular career. These career decisions help the individuals to achieve their occupational goals and high social status. Every nation of the world aspires towards quality of life and social status (Moy \& Lee, 2002). Career selection is one of many important choices students make in determining future plans. This decision will impart them throughout their lives. The essence of who the student is will revolve around what the student wants to do with their life long work (Battle, 2003).

Career is the totality of experience through which one learns about and prepares to engage in work as part of his way of living (Her \& Webb, 2004). A career is a sum of total work related experiences throughout a person's life (Jones, George, Hill, 2000). Career is denoted by getting jobs, moving between jobs, positions, levels of responsibilities and challenges (Hall, 2002). Arthur, Lawrence and Hall (2009) see career as an enjoying process that occurs over the lifespan and includes homes, schools and community. Every human being needs to do one job or the other to help contribute to the development of the country. Career can be subjectively determined when it depends on the individuals explanation as a sequence of attitudes and behaviour related to his or her working experience. On the other hand, career can be objectively determined by getting first, the job, moving between different jobs and tasks, levels of responsibility and different challenges (Peck, 2003). As such many are confronted by the problem of career choice as either individuals faced with problems of choosing careers for themselves, parents helping their children to select between careers, and teachers or career officers or psychologists who as part of their daily work, offer career guidance to students (Ferriera, Tavares \& Hestaley, 2006).

The choice of career has been a serious problem among the secondary school students in Nigeria. No matter what ones' age is, this choice of career is an important question for everybody. A lot of students in secondary schools believe that their future is a glorious adventure in which they are bound to succeed (Morrison, 2004). Many of them have ideas of working in public or private establishments as soon as they complete their secondary school education. Some have planned to become lawyers, engineers, medical doctors, accountants and so on (Baruch, 2006). Students in secondary schools, like many other young adults, are always worried about what they will do with their lives, the kind of adult they will become, and many other worries (Her \& Webb, 2004). How the young people of today meet the problems of tomorrow will depend upon the amount of success they make in planning for that tomorrow (Yakushko, 2006). Planning for tomorrow itself, is primarily the responsibility of parents, teachers, and the school counsellor (Hardy, 2009). 
Every student carries the unique history of their past and this determines how they view the world. That history is created in part by the student's environment, personality and opportunity. It will also determine the career choices students make (Greenwood, 2000). The environment, as one of the factors in career choice may influence the career students choose. For example, students who lived by creeks, lakes and rivers may choose a career dealing with the water. Another determinant or factor in career choice could be role models, where someone in the student's life has made a significant impact or impression, leading to a definite career choice. Parents and their educational backgrounds may also influence the student's views on whether or not to continue their quest for a particular career (Moursund, 2010).

Students have seen themselves in a role in which personality is a determining factor that may influence a chosen career. Some careers demand that you have the personalities to match the qualities of the occupation (Greenwood, 2000). For example, sales people have to be out going. Splaver (2000) opined that personality plays an important role in the choosing of the right career. A student's personality must be a self-motivated type, as to investigate career possibilities from early on in their lives and not the procrastinating type that wants until they are compelled to decide. Students must take seriously, the role academic performance play in limiting opportunities in the future.

Opportunity is one of the factors that have shaped career choices for students. Opportunity may influence how students have perceived their future in terms of the reasonable probability of a future in particular career fields. The issue of poverty has played an important determining role in the opportunities available to all.

The study of mathematics and its relevance in our everyday life cannot be underestimated as it applies to various and numerous disciplines. In secondary schools in Nigeria, students tend to run from mathematics, mostly because the subject is perceived as being difficult by the individuals in the society. Amongst these negative perceptions, a handful of secondary school students unknowingly seek to venture into mathematical related careers such as engineering, computer science and mathematics in the sciences, and accounting, banking and finance, mathematics education, among others in the arts and social sciences. There are deferent determinants that interplay and influence secondary school students' choice of venturing into mathematics-related courses. These determinants are considerately many, but for the course of this study, just seven (7) of these determinants are going to be analysed. They are; parents influence, peer group influence, role models influence, teaching methods in schools, students' academic ability, gender differences and students interest

Parents are considered the primary determinants of the students' choice of career, because the home is the first agent of socialisation. This insinuates that before external factors influence the students' decision on what career to choose, the student would have encountered in one way or another, information concerning his or her choice of career from his or her parents at home (Rocca, 2013). Zody, McDermid, Schrank and Sprenkle (2006) opined that students whose parents own and operate in small businesses may want or feel obligated to follow in their parents footsteps. Whether this is obtainable for students with parents having mathematical backgrounds is still largely unclear, particularly for students in Makurdi metropolis, Benue State Nigeria. 
Also, trends and peer groups are important for individual socialisation as well as behavioural modification. While such groups include same age group, its formation is dependent on multiple factors including situation, an accident or association, among others (Bochert, 2002). Alberts, Mbalo and Ackerman (2003) opined that though the development of a child is initially the outcome of the family, peers overtake the socialisation process with the selection and adoption of lifestyle, appearance, and social and academic activities. These factors eventually turn out to be heavy influences of many key decisions for an individual.

Role models, who could be active determinants in the students' choice of career may be basically family and friends who are considered to be the primary and basic influential parts of students' life (Wildman \& Torres, 2002). Fadipe (2003) was of the view that teachers as a role models are basic influential structures for the child's future development. This statement makes the teacher an active role model for the student as well as the family and friends.

Teaching methods in schools can also influence the students' choice of career, particularly as a teacher who employs and emphasizes practical skills and makes use of relevant instructional materials and laboratory equipment has a higher chance of bringing up students who are inclined to science (Porter \& Umbach, 2006). However, a passive teacher who is inclined to dictating in class at all times tends to bring up students who would take after art courses (Porter \& Umbach, 2006). The quality of mathematics instruction available to students determines their interest in the discipline.

Another determinant of students' choice of a career is the student's academic ability. Many students choose their career base on their academic ability (Beggs, Bantham \& Taylor, 2008). Some students do not have the ability or the work habit to succeed in some courses, like mathematics-related ones, that may require intensive study. Some of these students' career choices are forced on them mostly because they failed to achieve a particular academic bench mark for their prior career choice (Alfred-Davidson, 2009). This trend is particularly noteworthy in Nigeria, where the haphazard placement of students by institutions of higher learning often left these young adults with little or no choice.

Gender is also an active determinant in students' choice of career. In the past, gender roles in the work force have been uneven and unfair as women usually had lower paying jobs than men (Bronstein \& Farnsworth, 2001).Currently, the playing field between the two are more even. However, when looking at the work force, you can still find men and women in stereotypical job fields (Greenwood, 2000).

Students' interest is a great determinant in the choice of a career as some students grow up knowing exactly what they want to major in. These are students who will go extra miles to reach their dream job (McGlynn, 2007). Such students will research their chosen career path and explore everything about it. The salary and benefits of that job most times do not play a role in this decision (Beggs, Bantham \& Taylor, 2008).

Considering the pivotal role of mathematics as a subject in the choice of a future career among senior secondary school students, this study seeks to investigate the dynamics of some factors and determinants in mathematics-related career choices. How do specific determinants such as parents, peer group, role models, among others, influence mathematics related career choices of Senior 
Secondary School students in Makurdi metropolis, Benue State, Nigeria? This and other pertinent concerns form the basis of this study.

\section{THEORETICAL FrAMEWORK}

In the past few decades, the theory by John L. Holland (1919-2008), professor emeritus of sociology at John Hopkins University has guided career interest assessment across the globe (Leung, 2008). The Holland' theory of career development offers simple and easy to understand typology framework on career interest and environments that could be used in career counselling and guidance. Holland postulated that vocational interest could be conceptualised into six typologies, which are Realistic(R), Investigative (I), Artistic (A), Social(S), Enterprising (E) and Conventional(C). If a person's degree of resemblance to the six vocational personality and interest types could be assessed, then it is possible to generate a three-letter code, for example (SIA, RIA) to denote and summarise ones career interest (Hampton, 2005). The first letter of the code is a person's primary interest type, which would likely play a major role in career choice and satisfaction. The second and third letters are secondary interest and would likely play a lesser but still significant role in the career choice process (Patton, Bartrum \& Creed, 2004).

The six Holland's interest typologies are arranged in a hexagon in the order of RIASEC, and the relationship between the types in terms of similarities and dis-similarities are portrayed by the distance between corresponding types in the hexagon. The concept of consistency is used as "á measure of the internal harmony or coherence of an individual's type scores" (Spokane \& CruzaGuet, 2005, p.24). Accordingly, types that are adjacent to each other in the hexagon have the least degree of similarity in terms of their personal characteristics and vocational orientations, types that are opposite in the hexagon have the least degree of similarity and types that are separated by one interval have a moderate degree of similarity. A simple way to determine the consistency of an internal code is to look at the distance between the first two letters of the code in the Holland's hexagon (high, moderate or low consistency).

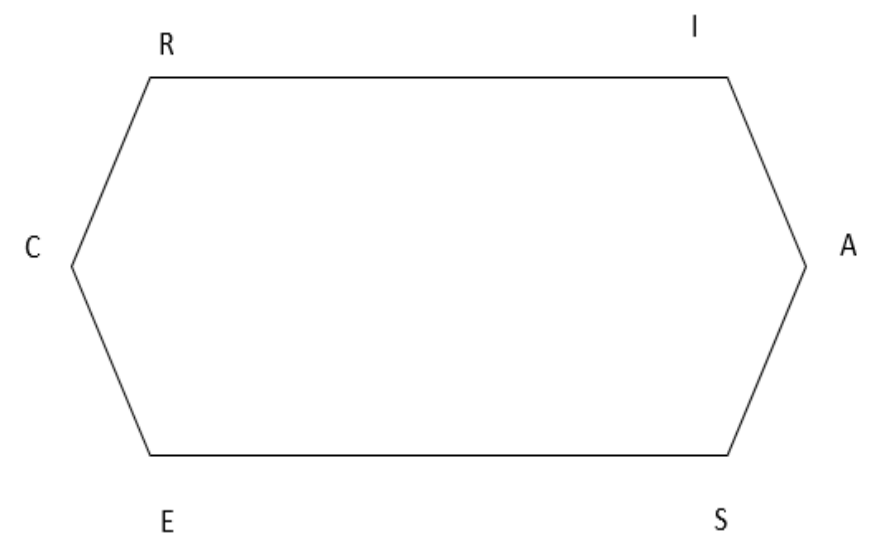

Figure 1: Hexagon of the Hollands Codes (Source: Leung, 2004)

Based on Holland's theory, it would be relatively easy for teachers and counsellors to determine a student's personality type and hence guide the student towards achieving a career that his personality indicates in choosing a mathematics related career. Students interest is pivotal in 
determining a student's choice of career, as when a student majors in a career he/she likes, it increases the effectiveness of the student in that field and in the long run, assists the student in achieving his/her career goals. This implies that students in Makurdi metropolis, Benue State, Nigeria, whose interests are mathematics-inclined have a higher possibility of succeeding in mathematics related careers as compared to students whose interests are not mathematics-related.

Another related framework, the social cognitive career theory (SCCT) was developed by Robert W. Lent, Steven D. Brown and Gail Hackett in 1994. This theory is based on Albert Bandura's general social cognitive theory (1986), an influential theory of cognitive and motivational processes that has been extended to the study of many areas of psychosocial functioning, such as academic performance, health behaviour and organisational development (Leung, 2004). Social cognitive career theory (Lent, Brown, \& Hackett, 2002) is anchored in Bandura's self-efficacy theory (1977, 1997), which postulated a mutually influencing relationship between people and the environment (Lent, 2005). SCCT offers three segmental, yet interlocking process models of career development seeking to explain the development of academic and vocational interest, how individuals make educational and career choices, and finally, educational and career performance and stability. The three segmental roles have different emphasis centring around three core variables, which are selfefficacy, outcome expectations and personal goals.

Lent (2005) defined self-efficacy as "a dynamic set of beliefs that are linked to a particular performance domains and activities" (p.104). Self-efficacy expectations influence the initiation of specific behaviour and the maintenance of behaviour in response to barriers and difficulties. Consistent with early formulation of Bandura (1977) and others (Hackett and Betz, 1981; Betz, Bortgen \& Harmon, 1996), SCCT theorized that self-efficacy expectations are shaped by fair primary information sources or learning experiences, which are personal performance accomplishments vicarious learning, social persuasion and psychological and affective states. Lent (2005) suggested that of the four sources of information in learning experience, personal performance accomplishments have the most powerful influence on the status of self-efficacy. Lent, Brown and Hackett (2002) defined outcome expectation as "personal beliefs about the consequences or outcomes of performing particular behaviour" (p.262). Outcome expectations include beliefs about extrinsic rewards associating with performing the tangent behaviour, selfdirected consequences, and outcomes derived from task performance. Over all, it is hypothesized that an individual's outcome expectations are formed by the same information or learning experiences shaping self-efficacy beliefs. Personal goals refer to one's intention to engage in certain activity or to generate a particular outcome (Lent, 2005). SCCT distinguished between choice content goals, referring to the choice of activities to pursue and performance goals, referring to the level of accomplishment or performance goals, erring to the level of accomplishment of performance one aims to attain (Leung, 2008). Through setting personal goals, individuals could persist I tasks and sustain their behaviour for a long time in the absence of tangible external rewards or reinforcement.

The SCCT choice model views the development of career goals and choices as functions of the interaction among self-efficacy, outcome expectations and interest over time (Law, Wong \& Leung, 2001). Career choice is an infolding process in which the person and his or her environment mutually influence each other. It involves the specification of primary career choice goal, actions aiming to achieve one's goal, and performance experience providing feed back to the individual on 
the suitability of the goal. In addition, SCCT posited that compromises is personal interest might be required in the career choice process due to contextual immediate to the person for example, cultural beliefs, social barriers, lack of support. Lent (2005) suggested that incongruence between efficacy and objective ability would likely lead to undesirable performance. An optional point is a slightly overshot self-efficacy which would promote further skills utilization and development. SCCT offers a comprehensive framework to understand the development of career interest, career choice and performance that is grounded in self-efficacy theory. In the past decade, SCCT has generated a large number of research studies including some studies conducted with international samples (Arulmani, Van Laar \& Easton, 2003). For example, a study by (Nota, Ferrari, Solberg, \& Soresi, 2007) used a SCCT framework to examine the career development of Italian youths attending a university preparation program in Padua province. The authors found a positive relationship between the career indecision. For male students, the relationship between family support and career indecision was partially mediated by career search self-efficacy. These findings were consistent with the general SCCT carer choice models, and illustrated the importance of social support to career decision and efficacy. Overall, SCCT offers international career guidance practitioners and researchers an overarching framework to guide practice, as well as tangible propositions and hypothesis that could be tested empirically (Hampton, 2005). In addition to hypothesis testing, efforts are needed to develop or adapt existing instruments so that variables associated with SCCT could be tested via measures that are valid and reliable across cultures (Patton, Bartum \& Creed, 2004).

Based on the social cognitive career theory, self-efficacy, outcome expectations and personal goals which are three career variables in the SCCT theory can aid students to efficiently determine the kind of career they would want to venture in. Self-efficacy as a variable on its own influences the initiation of specific behaviour and the maintenance of such behaviour in response to barriers and difficulties, therefore students, through the understanding of the self-efficacy concept, could find a suitable career for themselves and irrespective of the situation and barriers or difficulties they seem to find themselves in, they would still summon the courage and perseverance to achieve their dream careers. Subsequently, outcome expectation and personal goals are just integral outcomes and results that would surface in such students when self-efficacy has been achieved and mastered. In order to achieve self-efficacy, Senior Secondary School students in Makurdi metropolis who want to major in mathematics related careers should not only depend on their teachers and what they've learnt in the classroom, but these students should learn to study on their own and study ahead of what they are taught in class. Also, Senior Secondary School students who want to major in a mathematics related career should learn to take their mathematics assignments seriously and these assignments should at least be attempted by the students as this would help the students in developing self-efficacy for subsequent effectiveness in their mathematics related careers.

Relatedly, the theory of circumscription and compromise was developed by Linda S. Gottfredson in 1981. It is a developmental theory of occupational aspirations. The theory dealt with the process by which occupational aspirations developed during the pre-school through the college years and the process by which occupational aspirations are sacrificed when they cannot be implemented. When compared to the more established career frameworks, such as Super's and Holland's theories, Gottfredson's theory of career developments is a more recent contribution. Gottfredson (1981, 1996, 2002, 2005) assumed that career choice is a process requiring a high level of 
Abah, Age, Agada

cognition proficiency. A child's ability to synthesized and organise complex occupational information is a function of chronological age progression as well as general intelligence (Leung, 2008)

Cognitive growth and development is instrument to the development of a cognitive map of occupation and conceptions of self that are used to evaluate the appropriateness of various occupational alternatives (Morrow, Raksha \& Castameda, 2001). In the recent revisions of her theory, Gottfredson's $(2002,2005)$ elaborated on the dynamic interplay between generic makeup and the environment. Generic characteristics play a crucial role in shaping the basic characteristics of a person, such as interests, skills and values, yet their expression is moderated by the environment that one is exposed to (Goh \& Yu, 2001). Even though generic makeup and environment play a crucial role in shaping the person, Gottfredson maintained that the person is still an active agent who could influence or mould their own environment. Hence, career development is viewed as a self-creation process which individuals look for avenues or niches to express their genetic proclivities within the boundaries of their own cultural environment (Tien, 2005). In contrast with the established notion that choice is a process of selection, Gottfredson's $(1981,1996,2002)$ theorised that career choice and development could instead be viewed as a process of elimination or circumscription in which a person progressively eliminates certain occupational alternatives from further consideration. Circumscription is guided by salient aspects of self-concept emerging at different developmental stages (Repetto, 2001). Gottfredson maintained that the career aspirations of children are influenced more by the public than private aspects of their self-concept (Leung, 2008). A development model was proposed consisting of four stages of circumscription. In the first called "orientation to size and power" (ages 3-5), the child perceives occupation as roles taken up by big people (adults). The second stage is called "orientation by sex roles"(ages 6-8), and in this stage, sex role norms and attitudes emerge as defining aspects of a child's self-concept. The child evaluates occupations according to whether they are appropriate to one's sex, and eliminates from further consideration alternatives that are perceived to be gender inappropriate (Leong \& Serafica, 2001). The third stage is called "orientation to social valuation" (ages 9-13) as social class and status become salient to the child's developing self-concept. According to (Brown \& Lent, 2005), the emerging adolescent eliminates from further consideration occupations that are too low or too high in prestige. The fourth stage is called "orientation to the internal, unique self" (ages 14 and above), in which internal and private aspects of the adolescents self-concept, such as personality, interest, sills and values, become prominent. The young adolescent considers occupations from the remaining pool of acceptable occupations according to their suitability or degree of match with one internal self (Leung, 2008).

According to Lips-Wiersma and McMorland, (2006) another career development process is compromise. In response to external realities and contrast, such as changes in the structure of the labour market, economic depression, unfair living practice, and family obligations, individuals have to accommodate their occupational preferences so that their eventual choices are achievable in real world. Compromise is a complex process in which compatibility with one's interest is often compromised first so as to maintain a greater degree of correspondence with one's preference for prestige and sex type (Leung, 2004). Since its inception in 1981, Gottfredson's theory has only achieved limited attention in the empirical literature. Swanson and Gore, (2000) commented that Gottfredson's theory is one of the few attempts to study specifically the period corresponding to 
Super's growth stage. However, it essentially remains quite difficult to test the theoretical propositions, and unfortunately, an untestable theory is not particularly useful. Nevertheless, the theory by Gottfredson still offers unique perspective to career guidance professionals internationally. For instance, gender stereotype is part of many culture, example, Asian cultures, and individuals are encouraged to pursue occupations that are perceived to be compatible to their gender (Leung, 2002). Hence, Gottfredson's theory offers framework in which the influence of prestige and sex type could be understood in diverse cultural contexts. Meanwhile, as career guidance interventions are becoming more central in primary and secondary schools around the world, (Gysbers, 2000) opined that the theory by Gottfredson could be used as a conceptual guide to programme development. Gottfredson (2005) outlined a model of career guidance interventions aiming to reduce risk and enhance development, encouraging positive adaptation in relation to cognitive growth, self-creation and compromise (Leung, 2004). The broad strategies of Gottfredson's theory of circumscription and compromise are applicable to a variety of cultural contexts in which opportunities exist for career interventions in school settings (Savickas, 2005).

In line with Gottfredson's theory, a child's ability to synthesize and organise complex occupational information is a function of chronological age progression as well as general intelligence. As a result, from the basic Junior Secondary School level where the subjects taught are of a general scope and not specific, as student's age progresses simultaneously with their classes, to the Senior Secondary School level, they would have established relevant information about their choice of career. Hence, the progression from the Junior Secondary to the Senior Secondary level is pivotal in a student's choice of career as it gives the students a more general view of the variety of career present to choose from, making their final choice of career at the senior secondary school level deductive from their previous knowledge and experiences while learning. The dynamics of gender, as exposed by Gottfredson, are known to be prevalent in the area covered by this present study.

\section{EMPIRICAL STUDIES}

Mirza, Syeda and Mirza (2004) conducted a research on determinants and influences of student's career choice. The objective of the study was to explore the influences and determinants that have effects on the decision of career selection. They opined that some of the determinants and influences were interests, demand of time, educational background, socio-economic background, opportunity, personality/gender, motivation and environment. Their target was students of Gurat City, Pakistan. However, the sampled population were students who enrolled in first year of intermediate. A sample of 380 students was drawn using stratified random sampling. In reliability analysis, the (cronbach Alpha = 0.84) was used and it was concluded that variables included in the study were reliable and the confirmatory factor analysis confirmed all the factors. The findings showed that educational background played the most important role in the determination of career selection and the characteristics of different groups of students who chose their career "by choice" or "by force" were explored using cluster analysis. Although the work or Mirza, Syeda and Mirza yielded a relatively positive result, the target population was students that were already in tertiary institution making the determinants of career choice selection too broad to analyse. Another context in which the study was broad is the fact that these determinants were determinants of various and numerous career choices. This present study aims at narrowing the research to mathematics related careers and the study is also limited to the Senior Secondary School level. 
Irfan, Nayyar and Muhammad (2012) investigated the determinants of educational career change decisions and their effects on sources of decisions. The study dealt with the selected professionals who have changed their career towards IT. A cluster of IT professionals from the target population was taken using the purposive sampling technique. A questionnaire was used as the instrument of data collection and as such, a total of 200 questionnaires were circulated in different government and private organisations and a total of 180 questionnaires were returned back having a response rate of $90 \%$. The objective of the study was to investigate the intensity of the relationship between determinants of educational career change decisions and their effects on success of decision using the Pearson correlation. The correlation values were found significant which showed that students mostly change educational career due to the perceived scope of IT in future. Unlike Irfan, Nayyar and Muhammad's work whose target population was professionals in the IT field, this current effort is aimed at finding the determinants of mathematics related career choice among Senior Secondary School students who are not yet professionals.

Olawale (2014) carried out a research on the determinants of the career choice of international students in South Africa. The primary objective of the study was to determine the factors that influence the career choice of international students in South Africa. The study used the quantitative research approach and a descriptive research design. Data for the research was gathered through the use of self-administered questionnaire in a survey. The participants in the survey were international students pursuing business related course at two universities locate in the Limpopo and Ganteng provinces of South Africa. Convenience and Snowball sampling methods were used to collect data from 75 respondents. The results indicated that there are multiple influences on the career choice of international students. The most important determinant of the career choice of international students pursuing business courses are the interests in the course, the prestige of the course, the prospect of well-paying jobs, the influence of parents and the subject assed at matric or equivalent level. While Olawale's study was targeted at international students in South Africa, and was also aimed at the determinants of business related career choices, this study is not aimed at international students per say, but senior secondary school students in Nigeria and this study is also aimed at finding the determinants of mathematics related career choices among these senior secondary school students. The only correlations between the determinants of Olawale's study and the determinants of this current study are the student's interest and the parents influence.

Adedapo, Sawant, Kobba and Bhise (2014) conducted a research on the determinants of career choice of agricultural profession among the students of college of agriculture in Maharashtra state, India. The purpose of the study was to identify factors that influence the career choice of agricultural profession among the students of college of agriculture, Maharashtra state, India. A total of 120 respondents were randomly selected for the study and a structured questionnaire was used to elicit information from the students. Descriptive statistics, likert scale and regression analysis was used to analyse the data collected, and the respondents ages ranged from 19-44years with an average age of 22.6years, the respondents also belonged to all the religions practiced in the country. More than half of the respondents were males and they belonged to farming families and also had rural backgrounds in their childhood. Seven variable significantly influenced the choice of career of agricultural profession which includes; personal interest (mean $=2.50$ ), guidance or mentor $($ mean $=2.15)$, parents $($ mean $=2.13)$, media or contacts with agricultural experts $($ mean $=$ 
$2.03)$, previous educational performance $($ mean $=2.01)$, location of childhood $($ mean $=1.96)$ and work experience before admitted into college of agriculture (mean =1.92). Most of the respondents perceived agriculture as a stepping stone to the other professions. In conclusion, the regression analysis result validates the significant relationship between influence of parents, mentor, educational performance, work experience, childhood background, family income, and parent occupation on the choice of agriculture as a course and profession among youths in the university. Adedapo, Sawant, Kobba and Bhise's study was limited to undergraduates in the agriculture field which varies significantly from this study. This present study is aimed at analysing the determinants of mathematics related career choices among senior secondary school students in Makurdi metropolis, Benue State.

\section{RESEARCH QUESTIONS}

The following research questions guide the study

i. To what extent do parents' influential decisions affect mathematics related career choices among senior secondary school students in Makurdi metropolis, Benue State?

ii. To what extent does a senior secondary school student's academic ability affect or influence his or her choice of a mathematical related career in Makurdi metropolis, Benue State?

iii. To what extent does peer group influence mathematics related career decisions among senior secondary school students in Makurdi metropolis, Benue state?

iv. To what extent do the various teaching methods employed by teachers influence the choice of mathematics related careers among secondary school students in Makurdi metropolis, Benue state.

v. To what extent does senior secondary school students' interest in mathematics influence the choice of mathematics related careers in Makurdi metropolis, Benue State?

vi. To what degree does gender difference influence the choice of mathematics related careers among senior secondary school students in Makurdi metropolis, Benue State?

vii. To what extent do role models influence mathematics related career choices among senior secondary school students in Makurdi metropolis, Benue state?

\section{Methodology}

The research design adopted for this study is the survey research design. The study was conducted in Makurdi metropolis, Benue State. Makurdi is the capital of Benue State in Nigeria. The population of this study is made up of the 5,464 Senior Secondary School II (SS2) students in the 52 secondary schools in Makurdi metropolis, Benue State, Nigeria.

A sample of 125 Senior Secondary School II (SS2) students was used for the study. The 125 students were selected using multistage sampling technique. Firstly, Makurdi metropolis was stratified into five major strata (towns), namely, Wadata, Northbank, High Level, Modern Market Area, and Wurukum. In the second stage, one secondary school was selected from each of the strata specified in this study using simple random sampling. In the third stage, only Senior 
Secondary School II (SS2) students were selected from each of the sampled secondary schools, and in the final stage, simple random sampling was applied again to select 25 SS2 students from each of the sampled schools in Makurdi metropolis, Benue State.

The Students Career Determinant Questionnaire (SCDQ) was the instrument used for data collection in this study. The SCDQ is a researcher developed questionnaire which is meant to extract responses from senior secondary school (SS2) students and subsequently, serve as an aid to analyse the determinants of mathematics related career choices among the sampled students. The SCDQ consists of 9 sections; A to J. Section A is the preliminary section which involves the students' basic data like school, gender and age. Section B on the other hand determines if the students' choice of career is mathematics related and section B consists of 5 questions. Section C contains 6 items and it investigates the extent parents influence a students' choice of a mathematics related career. Section D contains 6 items and like section C, it investigates whether students' academic ability has great influence on a students' choice of a mathematics related career. Section E comprises 4 items which investigates peer group as a determinant of mathematics related career decisions, section $\mathrm{F}$ which comprises 5 items seeks to infer whether teaching methods in schools has a great influence on students' choice of a mathematics related career. Section G investigates how students interest influence mathematics related career choice decisions and it comprises of 4 items. Section H considers how gender differences influences the choice of a mathematics related career among senior secondary school students and it consists of 4 items. Finally, section I (which has 5 items) investigates the extent to which role models influence mathematics related career choices among senior secondary school students in Makurdi metropolis, Benue State.

The structure of the SCDQ was developed using a 4 point Likert-type scale which comprises Strongly Disagree (SD), Disagree (D), Agree (A), and Strongly Agree (SA). Strongly Disagree was assigned a value of 1, Disagree was assigned a value of 2, Agree was assigned a value of 3 and Strongly Agree was assigned a value of 4. Subsequently, the benchmark was obtained by calculating the mean of the values attached to the scales. The value of the benchmark obtained was 2.50 which served as a basis for acceptance or rejection of the items in the SCDQ. As a result, any item with a mean that is less than 2.50 is rejected and any item with a mean that is greater than or equal to 2.50 is accepted.

The validation of the instrument was done by a mathematics expert from the University of Agriculture, Makurdi, Benue State and two mathematics teachers from two different secondary schools in Makurdi metropolis, Benue State. The validates were requested to go through the SCDQ thoroughly to check the language, relevance and appropriateness of the items in the questionnaire. Corrections and further suggestions were used to improve the SCDQ finally before it was administered to the respondents by the researcher. To ensure reliability, the SCDQ was trial-tested on 31 senior secondary school mathematics students who were selected from a secondary school (outside the sampled secondary schools in this study) in Makurdi metropolis, Benue State. Results obtained from the trial testing were subjected to reliability analysis yielding a Cronbach's Alpha Coefficient of 0.82 , indicating a high level of internal consistency among the items.

The SCDQ was administered to the sampled students directly by the researcher. The sampled students (respondents) filled the items in the SCDQ and received by the researchers after respondents had correctly responded to the items in the questionnaire. The data obtained from the 
SCDQ was subjected to statistical analysis using descriptive statistics. Mean and standard deviations were calculated to answer the research questions.

\section{RESULTS}

The presentation of results for this study is done according to the research questions

\subsection{Research Question One}

To what extent do parents' influential decisions affect mathematics related career choices among senior secondary school students in Makurdi metropolis, Benue State?

Table 1: Mean Score of Responses on Parents Influence on Mathematics Related Career Choice among Senior Secondary School Students in Makurdi Metropolis, Benue State

\begin{tabular}{llccc}
\hline S/N & Items & Mean & SD & Remarks \\
\hline 1. & My Parents/Guardians have a great influence on my career choice & 2.95 & 0.91 & Accepted
\end{tabular}

2. My Parents/Guardians career is Mathematics/Calculation related $\quad 2.44 \quad 1.12$ Rejected

3. My Parents/Guardians insist that I must do a mathematics related career $\quad 2.11 \quad 1.08$ Rejected

4. My Parents/Guardians suggest that I should pick a mathematics related $2.32 \quad 1.03$ Rejected career

5. My Parents/Guardians buy mathematics related books for me

$2.93 \quad 0.93 \quad$ Accepted

6. My Parents/Guardians chose my secondary school courses

$1.67 \quad 1.08 \quad$ Rejected

From the result in Table 1, there is an indication that parents and guardians buy mathematics related books for their wards, and parents and guardians also have great influence on mathematics related career choices of their children as indicated by item one (1). From items two and three, the responses indicate that Parents/guardians of secondary school students who would like to major in mathematics related career did not major in mathematics related careers and Parents/guardians do not insist that their children must go into careers that are related to mathematics respectively. Finally, items four and six indicate that parents/guardians do not really suggest their children 
should go into mathematics related careers and parents/guardians do not choose their children's secondary school courses.

\subsection{Research Question Two}

To what extent does a senior secondary school students' academic ability influence his choice of a mathematics related career in Makurdi metropolis, Benue State?

Table 2: Mean Score of the Responses on the Influence of Students Academic Ability on Mathematics Related Career Choices in Makurdi Metropolis, Benue State.

\begin{tabular}{llcll} 
S/N & Items & Mean & SD & Remark \\
\hline 1. & My Academic ability has a great influence on my career choice. & 3.10 & 0.95 & Accepted \\
2. $\quad$ I consider myself an average student in mathematics & 3.00 & 0.61 & Accepted \\
3. I consider myself a bright student in mathematics & 2.84 & 0.59 & Accepted \\
4. I consider myself below average in mathematics & 1.76 & 0.74 & Rejected \\
5. $\quad$ My classmates meet me to tutor them in mathematics often & 2.72 & 0.59 & Accepted \\
6. I often answer questions in mathematics classes & 2.94 & 0.60 & Accepted \\
& $\quad$ Cluster Mean & $\mathbf{2 . 7 3}$ & & Accepted
\end{tabular}

The result in Table 2 shows that academic ability influences the choice of a mathematics related career among senior secondary school students in Makurdi metropolis, Benue State. This deduction was made as a result of the cluster mean score of 2.73 for influence of academic ability which clearly is higher than the bench mark of 2.50. However, from item four (4), students rejected that they consider themselves below average in mathematics.

\subsection{Research Question Three}

To what extent does peer group influence mathematics related career decisions among senior secondary school students in Makurdi metropolis, Benue State?

Table 3: Mean Score of Responses on Peer Group Influence on Mathematics Related Career Decisions among Senior Secondary School Students in Makurdi Metropolis, Benue State.

\begin{tabular}{llccc} 
S/N & Items & Mean & SD & Remark \\
\hline 1. & I have a study group & 2.78 & 0.77 & Accepted
\end{tabular}


2. In my study group, we study mathematics often

$2.57 \quad 0.84 \quad$ Accepted

3. Most people in my study group are inclined to mathematics

$2.75 \quad 0.84 \quad$ Accepted related careers

4. My study group has a great influence on my career choice

$2.65 \quad 1.02 \quad$ Accepted

Cluster Mean

2.69

Accepted

In Table 3, the result shows that peer group influence on the choice of a mathematics related career among senior secondary school students in Makurdi metropolis, Benue State is high. This deduction was made as a result of the cluster mean score of 2.69 for peer group influence, which is obviously higher than the bench mark of 2.50

\subsection{Research Question Four}

To what extent do the various teaching methods employed influence the choice of a mathematics related career among senior secondary school students in Makurdi metropolis, Benue State?

Table 4: The Mean Score of the Responses on Influence of Various Teaching Methods Employed on Mathematics Related Career Choice Decisions among Senior Secondary School Students in Makurdi Metropolis, Benue State.

\begin{tabular}{|c|c|c|c|c|}
\hline $\mathbf{S} / \mathbf{N}$ & Items & Mean & SD & Remarks \\
\hline 1. & Mathematics classes in my school are interesting & 3.38 & 0.43 & Accepted \\
\hline 2. & I like the way my mathematics teacher teaches & 3.20 & 0.68 & Accepted \\
\hline 3. & I understand clearly when my mathematics teacher teaches & 3.11 & 0.74 & Accepted \\
\hline 4. & $\begin{array}{l}\text { My mathematics teacher is the reason for my success in } \\
\text { mathematics }\end{array}$ & 2.82 & 0.92 & Accepted \\
\hline 5. & $\begin{array}{l}\text { My mathematics teacher and the way he/she teaches has a great } \\
\text { influence on my career choice }\end{array}$ & 2.76 & 1.03 & Accepted \\
\hline & Cluster Mean & 3.05 & & Accepted \\
\hline
\end{tabular}

In table 4, the result indicates that the influence of the various teaching methods employed by mathematics teachers on the choice of mathematics related careers among senior secondary school students in Makurdi metropolis, Benue State is very high. Apparently, the cluster mean score of 3.05 which is also the highest of all the determinants is greater than the benchmark of 2.50 . 


\subsection{Research Question Five}

To what extent does senior secondary school students' interest influence the choice of mathematics related careers in Makurdi metropolis, Benue State?

Table 5: The Mean Score of Responses on Influence of Students Interest on Mathematics Related Career Choices among Senior Secondary School Students in Makurdi Metropolis, Benue State?

\begin{tabular}{|c|c|c|c|c|}
\hline $\mathbf{S} / \mathbf{N}$ & Items & Mean & SD & Remarks \\
\hline 1. & My interests (things I like) are mathematics related & 2.86 & 0.70 & Accepted \\
\hline 2. & Subjects in my school that involve calculations interest me & 3.10 & 0.44 & Accepted \\
\hline 3. & $\begin{array}{l}\text { I prefer subjects that involve calculations to those that involve } \\
\text { reading }\end{array}$ & 2.81 & 0.80 & Accepted \\
\hline 4. & $\begin{array}{l}\text { I'm interested in calculation related games like Sudoku, chess, } \\
\text { among others }\end{array}$ & 2.77 & 0.82 & Accepted \\
\hline & Cluster Mean & 2.89 & & Accepted \\
\hline
\end{tabular}

In Table 5, the result indicates that the influence of students' interest on the choice of mathematic related careers among senior secondary school students in Makurdi metropolis is high. This deduction was made as a result of the cluster mean score of 2.89 for students' interest which is also higher than the benchmark of 2.50 .

\subsection{Research Question Six}

To what degree does gender difference influence the choice of mathematics elated careers among senior secondary school students in Makurdi metropolis, Benue State?

Table 6: The Mean Scores of Respondents on Influence of Gender Differences on Mathematics Related Career Choices among Senior Secondary School Students in Makurdi Metropolis, Benue State

\begin{tabular}{lllll} 
S/N & Items & Mean & SD & Remarks \\
\hline 1. & I would consider a job held traditionally by the opposite sex & 2.40 & 1.05 & Rejected \\
2. & My gender has a great influence on my career choice & 2.75 & 1.03 & Accepted \\
3. $\quad \begin{array}{l}\text { Because my choice of career is mostly occupied by my gender, it } \\
\text { encourages me }\end{array}$ & 2.90 & 0.93 & Accepted \\
& $\begin{array}{l}\text { I picked a challenge to choose my career because my gender is } \\
\text { 4. } 2.53\end{array}$ & 1.08 Accepted \\
\hline
\end{tabular}


limited in that area

Cluster Mean

Accepted

In Table 6, the cluster mean score of 2.64 shows acceptance for the influence of gender on the choice of mathematics related careers among senior secondary school students in Makurdi metropolis, Benue State because it is higher than the benchmark of 2.50. However, from item one (1), it could be seen that the respondents rejected that they would consider jobs held traditionally by the opposite sex. They rejected the notion that since mathematics related careers are held traditionally by the masculine gender, there would be more male than female secondary school students in Makurdi metropolis, Benue State, who would love to go into mathematics related careers.

\subsection{Research Question Seven}

To what extent do role models influence mathematics related career choices among senior secondary school students in Makurdi metropolis, Benue State?

Table 7: The Mean Scores of the Responses on Role Models Influence on Mathematics Related Career Choices among Senior Secondary School Students in Makurdi Metropolis, Benue State

S/N Items $\quad$ Mean SD Remarks

1. The occupation of my role model is calculation/mathematics 2.950 .78 Accepted related

2. My role model has a great influence on my career choice

$2.89 \quad 0.84 \quad$ Accepted

3. My role model encourages me to do a mathematics related career $2.75 \quad 0.94$ Accepted because of his/her achievement in that area

4. My role model buys mathematics/calculation related textbooks $2.61 \quad 0.97$ Accepted and other relevant mathematics related materials for me

5. My role model insists I do a mathematics related career $\quad 2.22 \quad 0.97 \quad$ Rejected

Cluster Mean

2.68

Accepted

The results in Table 7 show that the cluster mean score of 2.68 for the influence of role models on the choice of mathematics related careers among senior secondary school students in Makurdi metropolis, Benue State is high. This deduction is made as a result of the cluster mean score of 2.68 which is greater than the benchmark of 2.50. However, in item five (5), the respondents rejected that their role models insist they do a mathematics related career. 


\section{Discussions}

Parental influence on career choices relating to mathematics is very pivotal. Although Parental involvement is important, parents do not choose their children's choice of career, at the same time, parents do not suggest or insist that their children must do a mathematics related career. Parents show their involvements in their children's career choices through some activities like buying of mathematics related books for their children to boost their children's choice of a mathematics related career. This outcome of this study is in line with Adeyemi (2012) who opined that family involvement includes the extent to which parents provide encouragement, responsiveness, approval and financial support in matters concerned with the career plans of their children.

Schools, being social institutions that reinforce appropriate behaviour, interest and occupations are important because teachers like parents are viewed as key players in career paths that young people eventually pursue because the teachers are the individuals who employ these various teaching methods that finally influence the choice of mathematics related careers among these secondary school students. From item 5 in Table 4, respondents indicate that their mathematics teacher and the way he/she teaches has a great influence on their various career choices that are mathematics related. This agrees with Kniveton (2004), Falaye and Adams (2008), and Mudhovozi and Chireshe (2012) conclusions that the various teaching methods employed by the teacher in a school is an important factor that influences career choice decisions. Creemers and Kyriakides (2006) identified eight teaching styles for educational effectiveness. They are; orientation, structuring, questioning, teaching modelling, application, classroom management, management of time and assessment. These teaching styles make up the dynamic model for educational effectiveness.

Peer group influences on career choices especially career choices relating to mathematics cannot be underestimated as through various study groups made up of peers, in the senior secondary schools, career choices are being selected and decisions are being made on such career choices. Gender difference on the other hand has its own way of influencing career choice decisions. For example, from item 1 in Table 6 , respondents rejected that they would consider jobs held traditionally by the opposite sex, this indicates that mathematics related career choices like engineering, architecture, among others that are held traditionally by the masculine gender would not be very well considered by the feminine gender. This agrees with Baharun, Awang and Padlee (2012) who maintained that while men place more importance on tactical and calculation related career activities, women would view safety as a pivotal factor in determining career choices. In recent times however, both men and women major in mathematics, tactical and calculated related careers. Beggs, Bantham and Taylor, (2008) opined that, the influence of gender stereotyping on career choice decisions is gradually reducing. As a result of this, both male and female Senior Secondary School students can major in any mathematics related career they choose.

Factors such as the personal interest of students integrated with their various academic performances in subjects, interests in tasks related to the career choice, in this case, mathematics related career choice, the fit between their personality and the needs of their career choice, confidence in achieving a related job and the need to make a decent salary all influence the choice of mathematics related careers among senior secondary school students. From item 1 in Table 2, respondents indicate that their academic ability has a great influence on their career choice in line 
with Edwards and Quinter (2012) who opined that personal interests and academic ability of students is one of the most important factors influencing mathematics related career decisions.

The place of role models in career choice decisions among Senior Secondary School students is very vast and important. The possibility of receiving a sponsorship/bursary or even a piece of advice from role models will serve as an encouragement to these Senior Secondary School students and can highly influence the choice of a mathematics related career among senior secondary school students. Role models involvement and activities such as high expectations from students by role models, prestige and status of role models occupations, teacher influences since the teacher is also a role model, all in concordance with one another have strong positive influences on mathematics related career choice among senior secondary school students. For instance, from item 2 in Table 7, respondents accepted that their role models have a great influence on their career choice which opposes the view of Sarwar and Azmat (2013) that role models influence on career choice is negligible as parental influences encompass all the spheres of a role models influence.

\section{Conclusion}

This study has provided insights into the various and numerous determinants of mathematics related career choices among senior secondary school students in Makurdi metropolis, Benue State. The study has also established that a major determinant of mathematics related career choice among senior secondary school students is the various teaching methods employed in schools. These outcomes have shown that the overall bringing up of a child is not a unitary responsibility of just the parents or the guardians, but also a collective, collaborative responsibility of both parents/guardians, teachers and even the society at large. Other important influences are peer group and role models. The interplay of these determinants have continued to steer Senior Secondary School students in Makurdi metroplis, Benue State to mathematics related careers like mathematics education, engineering, physics, architecture, accounting, statistics, banking and finance, among others.

\section{RECOMMENDATIONS}

The following recommendations are made based on the findings of this study:

i. Mathematics educators and educators in mathematics related subjects should incorporate various teaching methods in their teaching rather than using just one method as this may serve as the basis of career decisions related to mathematics for their students.

ii. Parents should view their roles in career decisions of their children as one of involvement rather than that of influence because apparently, parent's involvement in the choice of mathematics related careers is highly essential.

iii. Students, especially senior secondary school students should carefully select their peers as these peers have significant impacts on their choice of mathematics relate careers.

iv. In career selection, especially careers involving mathematics/calculations, secondary school students should consider their ability and interest in selecting subjects that are related to their choice career as students who just pick mathematics related careers without considering their academic ability in mathematics, physics and other 
calculation related subjects may face serious difficulties in future when they get involved In the career proper.

v. The influence of role models on mathematics related career decisions cannot be overlooked. Influential individuals in the society, especially those in mathematics related fields like engineering, accounting, architecture, among others should positively re-evaluate their lifestyles as various students look up to them and pick challenges as a result of their behaviour, attitudes and successes to embark on mathematics related careers.

\section{Limitations OF The STUdY}

This study, despite its strengths, was constrained by its focus on just seven mathematics related career determinants out of the many exposed in the literature review. The study was also limited to just Makurdi metropolis, Benue State, and the sampled students selected were only Senior Secondary School II (SS2) students.

\section{SUGGESTIONS FOR FURTHER STUDIES}

Based on the apparent limitations of this study, the following suggestion is proposed for further studies:

i. Future studies may seek to enlarge the scope of this study to encompass a wider geographical reach and consider more determinants of mathematics related careers among students.

ii. The three classes (SS1 - SS3) of the Senior Secondary School level of education may better refine the outcomes of similar studies in the future

\section{REFERENCES}

1. Adedapo, A. O., Sawant, P. A., Kobba, F. \& Bhise, R. N. (2014). Determinants of Career Choice of Agricultural Profession among the Students of College of Agriculture in Maharashtra state, India. IOSR Journal of Agriculture and Veterinary Science (IOSRJAVS).7(9), 12-18.

2. Akomolafe,D. (2003). Relationship between father's occupational status and their children's occupational preference. Journal of Research in Counselling Psychology, 4, 6-9.

3. Alfred-Davidson, T. (2009).High school counsellor and career specialists' perceptions of school practices that involve parents in students' career planning. PhD Diss., Dept. of Secondary Education University of Florida. United States, Florida.

4. Alberts, C., Mbalo, N. L. \& Ackermann, C. J. (2003). Adolescents' Perceptions of the Relevance of Domains of Identity Formation: A South African Cross-Cultural Study. Journal of Youth and Adolescence, 32 (3), 169-184. 
5. Arulmani, G., Van Laar, D., \& Easton, S. (2003). The influence of career beliefs and socioeconomic status on the career decision-making of high school students in India. International Journal for Educational and Vocational Guidance, 3, 193-204.

6. Baharun, R., Awang, Z., \& Padlee, S.F. (2011). International students' choice criteria for

7. selection of higher learning in Malaysian private universities. African Journal of Business Management, 5, 4704-4714.

8. Bailyn, L. (2003). Academic Career and Gender Equity. Lesson Learned from MIT. Gender and Work Organization

9. Bandura, A. (1977). Social learning theory. Englewood Cliffs, NJ: Prentice-Hall.

10. Bandura,A., Barbanelli,C., Caprara, G.V., \& Pastorelli,C. (2001). Self-Efficacy Beliefs as Shapers of Children's Aspirations and Career Trajectories. Child Development Journal, 72, 187-206.

11. Baruch, Y. (2006), Career development in organizations and beyond: balancing traditional and contemporary viewpoints. Human Resource Management Review, 16, 125-38.

12. Battle, B. 2003. 4-H, FFA helps shape leaders of tomorrow. The Tennessean. Nashville, TN.W.29.

13. Beggs, J.M, Bantham, J.H \& Taylor, S (2008). Distinguishing the factors influencing college

14. students' choice of major. College Student Journal. 42(2): 381.

15. Betz, N. E., Borgen, F. H., \& Harmon, L. W. (1996). Skills confidence inventory: Applications and technical guide. Palo Alto, CA: Consulting Psychologists Press.

16. Betz, N. E., Fitzgerald, L. F, \& Hill, R. E. (1989). Trait-factor theories: Traditional cornerstone of career theory. In B. Michael, D. T. Hall, \& B. S. Lawrence (Eds.), Handbook of career theory (pp. 26-40). New York: Cambridge University Press.

17. Borchert, M. (2002). Career choice factors of high school students. Retrieved December $5^{\text {th }}, 2016$ from :http://www2.uwstout.edu/content/lib/thesis/2002/2002borchertm.pdf (June $5,2014)$

18. Bronstein, P. and L. Farnsworth. 1998. Gender differences in faculty experiences of interpersonal climate and processes for advancement. Research in Higher Education.39(5), 557-585

19. Brown, D., \& Associate (Eds.). (2002) Career choice and development (4th ed.). San Francisco, CA: Jossey-Bass.

20. Brown, S. D., \& Lent, R. T. (Eds.). (2005). Career development and counseling: Putting theory and research to work. Hoboken, NJ: Wiley.

21. Creed, P, A., Patton, W., \& Prideaux, L. (2006). Causal relationship between career indecision and career decision-making self-efficacy: A longitudinal cross-lagged analysis. Journal of Career Development, 33, 47-65. 
22. Creemers, B. P. M., \& Kyriakides, L. (2006). Critical analysis of the current approaches to modelling educational effectiveness: The importance of establishing a dynamic model. School Effectiveness and School Improvement, 17, 347-366. http://www.rug.nl/staff/b.p.m.creemers/testing_the_dynamic_model_of_educational_effect iveness.pdf

23. Edwards, K., \& Quinter, M. (2012). Factors Influencing Students Career Choices among Secondary School students in Kisumu Municipality, Kenya. Journal of Emerging Trends in Educational Research and Policy Studies, 2 (2): 81-87

24. Fadipe JO (2003). Quality control in education: the teacher factor. In T.E. Ajayi and J. Fadipe (Eds) Skills improvement programme for effective performance of teachers in Nigerian schools. A publication of National Institute for Educational Planning and Administration (NIEPA), Ondo, 128-143.

25. Falaye, F.W., \& Adams, B.T. (2008). An assessment of factors influencing career decisions of in-school youths. Pakistan Journal of Social Sciences, 5(3): 222- 225

26. Ferreira, M.P., Tavares, A.T., \& Hestaley,W. (2006). Evolution of Industry Clusters through Spin-offs and the Role of Flagship Forms. In: A.T. Tavares and A. Teixeira(eds.) Multinationals, Clusters and Innovation. London,UK; Palgrave, pp.87-106

27. Filmer, D., \& Fox, L. (2013). Youth Employment in Sub-Saharan Africa. Journal of African Development Forum, pp. 15-17.

28. Geist, M. R., Webb, D. C., \& van der Kooij, H. (2008, January). The impact of curriculum change on teacher practice: The case of College Algebra. Paper presented at the annual Joint Mathematics Meetings (Mathematical Association of America \& American Mathematical Association), San Diego, CA.

29. Goh, D. S., \& Yu, J. (2001). Translating and validation of the Chinese form of the strong interest inventory. Applied Psychology: An International Review, 50, 252-268.

30. Gottfredson, L. S. (1981). Circumscription and compromise: A developmental theory of occupational aspirations [Monograph]. Journal of Counseling Psychology, 28, 545-579.

31. Gottfredson, L. S. (1996). Gottfredson's theory of circumscription and compromise. In D. Brown\& L. Brooks (Eds.), Career choice and development: Applying contemporary approaches to practice (3rd ed., pp. 179-232). San Francisco, CA: Jossey-Bass.

32. Gottfredson, L. S. (2002). Gottfredson's theory of circumscription, compromise, and selfcreation.In D. Brown \& Associate (Eds.), Career choice and development (4th ed., pp. 85148). San Francisco, CA: Jossey-Bass.

33. Gottfredson, L. S. (2005). Applying Gottfredson's theory of circumscription and compromise incareer guidance and counseling. In S. D. Brown \& R. T. Lent (Eds.), Career development and counseling: Putting theory and research to work (pp. 71-100). Hoboken, NJ: Wiley.

34. Greenwood, A.M. (2000). Gender and jobs: Sex segregation of occupations in the world. Journal of International Labour Review, 138(3), 341-343. 
35. Gysbers, N. C. (2000). Implementing a whole school approach to guidance through a comprehensive guidance system. Asian Journal of Counselling, 7, 5-17.

36. Hackett, G., \& Betz, N. E. (1981). A self-efficacy approach to career development of women. Journal of Vocational Behavior, 18, 326-339.

37. Hall, D.T. (2002): "Careers in and out of organizations", Foundations for Organizational Science, Sage Publications series, California-London-New Delhi

38. Hampton, N. Z. (2005). Testing the structure of the Career Decision Self-efficacy Scale Short Form among Chinese college students. Journal of Career Assessment, 13, 98-113.

39. Hardy, G.H. (2009). An introduction to the theories of numbers. Journal of American Mathematical Society. 35(6), 6-7

40. Her, F.S. (2003). American Labour and Great Depression. International Journal of Labour Research. 2(1), 9-24.

41. Her, T., \& Webb, D. C. (2004). Retracing a path to assessing for understanding. In T. A. Romberg (Ed.), Standards-Based Mathematics Assessment in Middle School: Rethinking Classroom Practice (pp. 200-220). New York: Teachers College Press.

42. Hesketh, B., \& Rounds, J. (1995). International cross-cultural approaches to career development. In W. B. Walsh \& S. H. Osipow (Eds.), Handbook of vocational psychology: Theory, research, and practice (2nd ed., pp. 367-390). Mahwah, NJ: Erlbaum.

43. Holland, J. L. (1996). The occupations finder. Odessa, FL: Psychological Assessment Resources.

44. Holland, J. L. (1985). Making vocational choices: A theory of vocational personalities and work environments (2nd ed.). Englewood Cliffs, NJ: Prentice-Hall.

45. Holland, J. H. (1997). Making vocational choices: A theory of vocational personalities and work environments (3rd ed.). Englewood Cliffs, NJ: Prentice-Hall.

46. Irfan,R., Nayyar,K., \& Muhammad, Z.(2012). Determinants of Educational Career Change Decisions and their Effect on Success of Decision: A Study of Professionals of it Sector. International Journal of Academic Research in Business and Social Sciences. 2(4), 1-2.

47. Jones,M.G., and Brader-Araje,L. (2002). The Impact of Constructivism in Education: Language Discourse and Meaning. American Communication Journal, 5(3).

48. Kniveton, B.H (2004). The influences and motivations on which students base their choice of career. Journal of Research in Education, 72: 47-59.

49. Leung, S. A. (2004, August). Methodological issues in conducting vocational psychology research in Chinese communities. Paper presented at the 28th International Congress of Psychology, Beijing, China.

50. Lips-Wiersma, M., \& McMorland, J. (2006). Finding meaning and purpose in boundaryless careers: A framework for study and practice. Journal of Humanistic Psychology, 46, 147-167. 
51. Lent, R. W., Brown, S. D., \& Hackett, G. (2002). Social cognitive career theory. In D. Brown \& Associate (Eds.), Career choice and development (4th ed., pp. 255-311). San Francisco, CA: Jossey-Bass.

52. Lent, R. W. (2005). A social cognitive view of career development and counseling. In S. D. Brown \& R. T. Lent (Eds.), Career development and counseling: Putting theory and research to work (pp. 101-127). Hoboken, NJ: Wiley.

53. Leong, F. T. L., \& Serafica, F. C. (2001). Cross-cultural perspective on Super's career development theory: Career maturity and cultural accommodation. In F. T. L. Leong \& Barak, A. (Eds.), Contemporary models in vocational psychology: A volume in honor of Samuel H. Osipow (pp. 167-205). Mahwah, NJ: Erlbaum.

54. Leung, S. A. (2002). Career counseling in Hong Kong: Meeting the social challenges. The Career Development Quarterly, 50, 237-245.

55. Leung, S. A. (2008). International Handbook of Career Guidance, The Chinese University of Hong Kong, Hong Kong SAR, China. J.A. Athanasou, R. Van Esbroeck (eds.), 115. Springer Science + Business Media B.V. 2008

56. McGlynn, A.P. 2007. Achieving the dream - What is it, and what's new? The Hispanic Outlook in Higher Education 18(4), 44-45.

57. Maze, R. (2002). Parents push college over service. Army Times, 62 (42), 24. EBSCOhost AN 6639265. Retrieved June 17, 2002, from wysisyg://bodyframe.40/http://ehostvgw6.e...leanTerm=vocational\%20guidance

58. Mirza, N.S., Syeda, T.Z., \& Mirza, A.A. (2014). Determinants and Influences on Students' Career Choice. Universal Journal of Management and Social Sciences. Vol. 4, No.3; March 2014

59. Morrison, J. (2004), Influences before and during medical school on career choices. Journal of Medical Education. 38, 230-231.

60. Morrow, S. W., Rakhsha, G., \& Castaneda, C. L. (2001). Qualitative research methods for multicultural counseling. In J. G. Ponterotto, J. M. Casas, L. A. Suzuki, \& C. M. Alexander (Eds.), Handbook of multicultural counseling (2nd ed., pp. 575-630). Thousand Oaks, CA: Sage.

61. Moursund,J.P., and Erskine,R.G. (2010). Integrative psychotherapy: The art and science of relationship. Victoria, Australia: Thompson/Brooks Cole.

62. Moy, J.W. and Lee, S.M. (2002), The career choice of business graduates: SMEs or MNCs?,Career Development International Journal. 7(6), 339-47.

63. Mudhovozi, P., \& Chireshe, C. (2012). Socio-demographic factors influencing career decision-making among undergraduate psychology students in South Africa. Journal of Social Sciences, 31(2): 167-176. 
64. Nota, L., Ferrari, L., Solberg, V. S. H., \& Soresi, S. (2007). Career search self-efficacy, family support, and career indecision with Italian youth. Journal of Career Assessment, 15, 181-193.

65. Olawale, F. (2014). The Determinants of the Career Choice of International Students in South Africa. Mediterranean Journal of Social Sciences MCSER Publishing, Rome-Italy. November 2014, Vol .5 No. 23 ISSN 2039-2117

66. Patton, W., Bartrum, D. A., \& Creed, P. A. (2004). Gender differences for optimism, selfesteem, expectations and goals in predicting career planning and exploration in adolescents. International Journal for Educational and Vocational Guidance, 4, 193-209.

67. Peck, S.R. (2003): "Exploring the link between organizational strategy and the employment relationship: The role of human resources policies, Journal of Management Studies, 31(5), 715-736

68. Porter, S.R. and Umbach, P.D. (2006). College major choice: An analysis of personenviroment. Journal of Research in Higher Education. 47(4), 429-449.

69. Repetto, E. (2001). Following Super's heritage: Evaluation of a career development program in Spain. International Journal for Educational and Vocational Guidance, 1, $107-120$.

70. Richardson, M. S. (1993). Work in people's lives: A location for counseling psychologists. Journal of Counseling Psychology, 40, 425-433.

71. Rocca, S.J. 2013. Comparison of factors influencing the college choice of matriculant and nonmatriculant students into a college of agriculture. NACTA Journal. 57(2): 72-78.

72. Salami, S.O. (2006). Influence of culture, family and individual differences on choice of gender-dominated occupations among female students in tertiary institutions. Journal of Gender and Behaviour,4(2): 814-833

73. Sarwar, A., Azmat, A. (2013). Factors Having Impact on the Career Decisions: Study of Business Graduates in Pakistan. Business Management Dynamics Journal, 2(7): 9-19.

74. Savickas, M. L. (2005). The theory and practice of career construction. In S. D. Brown \& R. T.Lent (Eds.), Career development and counseling: Putting theory and research to work (pp. 42-70). Hoboken, NJ: Wiley.

75. Schacter,D.L. (2001). Forgotten ideas, neglected pioneers: Richard Semon and the Story of Memory. Philadelphia: Psychology Press. (re-issue of stranger behind the engram). Retrieved December, 2016 from http://www.psypress.com/books/details/9781841690520/

76. Spokane, A. R., \& Cruza-Guet, M. C. (2005). Holland's theory of vocational personalities in work environments. In S. D. Brown \& R. T. Lent (Eds.), Career development and counseling: Putting theory and research to work (pp. 24-41). Hoboken, NJ: Wiley.

77. Su, B.W. 2004. The U.S. Economy to 2012: signs of growth. Monthly Labor Review Journal.127(2):23-36. 
78. Tien, H. S. (2005). The validation of the career decision-making difficulties scale in a Chinese culture. Journal of Career Assessment, 13, 114-127.

79. The Economist.2013. Did living standards improve during the Industrial Revolution?

80. www.economist.com/blogs/freeexchange/2013/09/economic-history-0 The Economist Newspaper Limited 2013.

81. The Princeton Review.2013. Top 10 college majors. www.princetonreview.com/college/top-tenmajors.aspx TPR Education IP Holdings, LLC. 11/8/2013.

82. Wildman, M.L. and R.M. Torres. 2002. Factors influencing choice of major in agriculture. NACTA Journal. 46(3), 4.

83. Yakushko, O. (2006). Career development of immigrant women. In W. B. Walsh \& M. J. Heppner (Eds.), Handbook of Career Counseling for Women (pp. 387-426). Hillsdale, NJ: Lawrence Erlbaum

84. Zody, Z .,S. MacDermid, H. Schrank, \& D. Sprenkle. (2006). Boundaries and the functioning of family and business systems. Journal of Family and Economic Issues. 27(2), 185-206.

85. Zunker, V. G. (2002). Career counseling: Applied concepts of life planning (6th ed.). Pacific Grove, CA: Brooks/Cole.

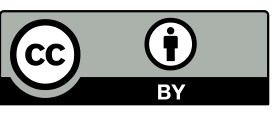

(C) 2017 by the authors. Submitted for possible open access publication under the terms and conditions of the Creative Commons Attribution (CC BY) license (http://creativecommons.org/licenses/by/4.0/). 